doi: $10.2306 /$ scienceasia1513-1874.2012.38.129

\title{
Preventive role of mirtazapine in methotrexate induced nephrotoxicity in rats
}

\author{
Hulya Uzkeser $^{\mathrm{a}}$, Ebru Sener ${ }^{\mathrm{b}}$, Ebubekir Bakan ${ }^{\mathrm{c}}$, Ahmet Hacimuftuoglu ${ }^{\mathrm{d}, *}$ \\ a Erzurum Regional Research and Training Hospital, Department of Physical Medicine and Rehabilitation, \\ 25240, Erzurum, Turkey \\ b Erzurum Regional Research and Training Hospital, Department of Pathology, 25240, Erzurum, Turkey \\ c Faculty of Medicine, Department of Biochemistry, Ataturk University, 25240, Erzurum, Turkey \\ d Faculty of Medicine, Department of Pharmacology, Ataturk University, 25240, Erzurum, Turkey
}

*Corresponding author, e-mail: hacimuftuoglu@gmail.com

Received 5 Jan 2012

Accepted 12 Mar 2012

\begin{abstract}
Methotrexate (MTX) is used in the treatment of rheumatic diseases, psoriasis, and cancer. Since more than 90\% of MTX is excreted via the kidneys, nephrotoxicity is one of the most important reasons restricting the use of this drug. In our study, we aimed to evaluate biochemical and histopathological properties to determine whether mirtazapine has a protective effect on MTX-related nephrotoxicity in rats. A group of rats were given a dose of $30 \mathrm{mg} / \mathrm{kg}$ of mirtazapine orally through a tube and $1 \mathrm{~h}$ after a dose of $5 \mathrm{mg} / \mathrm{kg}$ of MTX intraperitoneally. The rats in the control group received MTX alone intraperitoneally. A group of healthy rats was given orally distilled water in equal volume as dissolvent, then distilled water was administered intraperitoneally $1 \mathrm{~h}$ later. These procedures were repeated for 7 days. At the end of this period, all animals were sacrificed by giving a high dose of sodium thiopental. The results of biochemical analysis revealed that in the kidney tissues of rats given MTX, malondialdehyde, myeloperoxidase, glutathione, glutathione S-transferase, and nitric oxide levels were $42.3 \pm 2.4 \mu \mathrm{mol} / \mathrm{g}$ protein, $31.3 \pm 1.9 \mathrm{U} / \mathrm{g}, 6.5 \pm 1.0 \mathrm{nmol} / \mathrm{g}$ protein, $5.7 \pm 0.8 \mathrm{U} / \mathrm{g}$, and $14.7 \pm 1.2 \mu \mathrm{mol} / \mathrm{g}$, respectively; in the mirtazapine group, these values were found to be $24.2 \pm 1.9 \mu \mathrm{mol} / \mathrm{g}$ protein, $19.7 \pm 1.8 \mathrm{U} / \mathrm{g}, 11.5 \pm 1.3 \mathrm{nmol} / \mathrm{g}$ protein, $10.5 \pm 1.1 \mathrm{U} / \mathrm{g}$, and $25.2 \pm 2.7 \mu \mathrm{mol} / \mathrm{g}$, respectively. No biomarkers for protein nitrosylation, nitration, or DNA damage were measured. In this study mirtazapine was found to be efficacious to prevent nephrotoxicity due to MTX, suggesting that MTX can be used safely in higher doses and for a longer course in combination with mirtazapine in cancer chemotherapy.
\end{abstract}

KEYWORDS: oxidative/nitrosative stress, depression, inflammation

\section{INTRODUCTION}

Methotrexate (MTX), a cytotoxic chemotherapeutic agent, is used in the treatment of acute lymphoblastic leukaemia, lymphoma, osteosarcoma, breast cancer, head and neck cancers and also in the therapy of non-oncologic disorders such as rheumatic diseases and psoriasis ${ }^{1-4}$. High-dose methotrexate interrupts synthesis and repair of DNA and cell division by inhibiting several enzymes of the folic acid cycle. However, beside the therapeutic effects, there are also toxic effects including nephrotoxicity as well as gastrointestinal, central nervous system, hepatic, and bone marrow toxicity. Since more than $90 \%$ of MTX is excreted via the kidneys, nephrotoxicity is one of the significant reasons for restricting its use $^{5-7}$. The main damages caused by MTX in the kidneys occur in a wide clinical range, varying from subclinical tubulopathy to acute renal failure ${ }^{8}$. The increased production of reactive oxygen radicals is defined as one of the important causes of MTX-related renal toxicity. The use of MTX causes increased activities of malondialdehyde (MDA) and myeloperoxidase (MPO) and a decline in glutathione level in the kidneys and in other tissues ${ }^{9}$. Furthermore, it is suggested that excessive nitric oxide (NO) production has an impact on renal damage developed due to MTX administration ${ }^{10}$. These studies indicate that oxidative damage is an important mechanism involved in the pathogenesis of MTX-related nephrotoxicity. For this reason, it was thought that anti-oxidant therapy could be helpful to prevent or to ameliorate MTX nephrotoxicity. Studies have showed that several antioxidants are protective in MTX nephrotoxicity. However, MTX-related toxicity still remains one of the significant causes restricting its use in desired doses. Hence several trials have thus far been performed to ameliorate MTX toxicity.

An antidepressant is a psychiatric medication used to alleviate mood disorders, such as major de- 
pression and dysthymia, and anxiety disorders such as social anxiety disorder. Drugs including the monoamine oxidase inhibitors, tricyclic antidepressants, tetracyclic antidepressants, selective serotonin reuptake inhibitors, and serotonin-norepinephrine reuptake inhibitors are most commonly associated with the term. Mirtazapine is a tetracyclic antidepressant used primarily in the treatment of depression. Human studies and animal models of depression provide evidence that oxidative and nitrosative stress (O\&NS) pathways are involved in treatment resistance ${ }^{11}$. So there is a relation between antidepressant agents and O\&NS. Studies also suggest that major depressed patients could benefit from treatments with selected antioxidants ${ }^{11}$.

In addition, mirtazapine prevents ischaemia-reperfusion induced oxidative stress in kidney tissue ${ }^{12}$. Mirtazapine inhibits the production of both enzymatic and non-enzymatic oxidant parameters in the stomach tissue but increases the anti-oxidants ${ }^{13}$. Thus mirtazapine could be a protective agent in MTXinduced nephrotoxicity. In a literature reviews, we did not find any information or innovation relating to protective effects of mirtazapine on MTX induced renal toxicity. For this reason, the goal of our study is to ascertain biochemically and histopathologically whether mirtazapine has any protective effect on MTX induced nephrotoxicity in rats.

\section{MATERIALS AND METHODS}

\section{Animals}

In this study, a total of 18 Wistar albino male rats with weights varying between 220-235 were used, which were supplied from Ataturk University Practice and Research Centre for Medical Experiments. Before the study, the animals were kept and fed in groups at room temperature $\left(22^{\circ} \mathrm{C}\right)$. Animal experiments were performed in accordance with national guidelines for the use and care of laboratory animals and approved by the local animal care committee of Ataturk University.

\section{Chemical substances}

Of the chemical substances used for the experiments, thiopental sodium was provided by IE UlagayTurkey and mirtazapine was obtained from Organon Pharmaceuticals-USA. MTX was provided by Kocak Farma-Turkey.

\section{General procedure}

Rats to be used in the study were divided in to three groups to undergo (i) methotrexate (MTX), (ii) methotrexate + mirtazapine $(\mathrm{MTX}+\mathrm{Mrtz})$, and (iii) intact.

\section{Performing study}

In this series of our trial, a group of rats were given a dose of $30 \mathrm{mg} / \mathrm{kg}$ of mirtazapine orally through a tube. A dose of $5 \mathrm{mg} / \mathrm{kg}$ of MTX was given via intraperitoneal route $1 \mathrm{~h}$ after mirtazapine administration. The rats in the control group were injected MTX alone using the same route. The group of healthy rats was given orally distilled water in equal volume as dissolvent, then distilled water was administered intraperitoneally $1 \mathrm{~h}$ later. These procedures were repeated for 7 days. At the end of this period, all animals were sacrificed by giving an overdose of sodium thiopental. Their kidneys were extracted to perform biochemical analysis and histopathological examination. The results obtained from mirtazapine group were compared with those achieved from MTX group and control group.

\section{Biochemical analysis}

Venous blood samples were collected into tubes without anticoagulant. Serum was separated by centrifugation after clotting and stored at $-80^{\circ} \mathrm{C}$ until assayed. Creatinine and urea levels were determined in Cobas 8000 (Roche) spectrophotometrical system with colorimetric method. BUN (blood urea nitrogen) levels were determined with formula (BUN $=U \mathrm{URE} \times 0.48)$.

In alkaline solution, creatinine forms a yelloworange complex with picrate. The colour intensity is directly proportional to the creatinine concentration and can be measured photometrically (505 nm). Assays using rate-blanking minimize interference by bilirubin. Serum and plasma samples contain proteins which react non-specifically in the Jaffe method. Serum and plasma results must be corrected by $0.3 \mathrm{mg} / \mathrm{dl}(26 \mu \mathrm{M})$ to obtain accurate values. This correction causes a measurement error of $\leqslant 1 \%$ in urine specimens because these do not contain nonspecific proteins.

Urea is hydrolysed by urease to form $\mathrm{CO}_{2}$ and ammonia.

$$
\mathrm{Urea}+\mathrm{H}_{2} \mathrm{O} \stackrel{\text { urease }}{\longrightarrow} 2 \mathrm{NH}_{4}^{+}+\mathrm{CO}_{2}
$$

The ammonia formed then reacts with $\alpha$-ketoglutarate and NADH in the presence of GLDH to yield glutamate and $\mathrm{NAD}^{+}$.

$$
\begin{aligned}
& \alpha \text {-ketoglutarate }+\mathrm{NH}_{4}^{+}+\mathrm{NADH} \\
& \stackrel{\text { GLDH }}{\longrightarrow} \text { L-glutamate }+\mathrm{NAD}^{+}+\mathrm{H}_{2} \mathrm{O}
\end{aligned}
$$

The decrease in absorbance due to consumption of NADH is measured kinetically. The NADH complex to decrement is determined photometrically $(340 \mathrm{~nm})$. 


\section{Biochemical analysis of kidney tissue}

After the macroscopic analyses, the malondialdehyde (MDA), myeloperoxidase (MPO), glutathione (GSH), glutathione S-transferase (GST), and nitric oxide (NO) levels and enzyme activities in rat kidney tissues were determined. For this purpose, rat kidneys were frozen at $-80{ }^{\circ} \mathrm{C}$ before until biochemical investigations. To prepare the tissue homogenates, kidney tissues were ground with liquid nitrogen in a mortar. The ground tissues $(0.5 \mathrm{~g}$ each) were then treated with $4.5 \mathrm{ml}$ of an appropriate buffer, homogenized on ice using an Ultra-Turrax homogenizer for $15 \mathrm{~min}$, filtered, and centrifuged using a refrigerated centrifuge at $4{ }^{\circ} \mathrm{C}$. The supernatants were used to determine the enzymatic activities. All assays were carried out at room temperature in triplicate.

\section{Determination of lipid peroxidation or MDA formation}

The concentrations of gastric mucosal lipid peroxidation were determined by estimating MDA using the thiobarbituric acid test ${ }^{14}$. Briefly, the rat stomachs were promptly excised and rinsed with cold saline. To minimize the possibility of haemoglobin interfering with free radicals, any blood adhering to the mucosa was carefully removed. The corpus mucosa was scraped, weighed, and homogenized in $10 \mathrm{ml}$ of $100 \mathrm{~g} / \mathrm{l} \mathrm{KCl}$. The homogenate $(0.5 \mathrm{ml})$ was added to a solution containing $0.2 \mathrm{ml}$ of $80 \mathrm{~g} / 1$ sodium lauryl sulphate, $1.5 \mathrm{ml}$ of $200 \mathrm{~g} / \mathrm{l}$ acetic acid, $1.5 \mathrm{ml}$ of $8 \mathrm{~g} / \mathrm{l}$ 2-thiobarbiturate, and $0.3 \mathrm{ml}$ distilled water. The mixture was incubated at $98^{\circ} \mathrm{C}$ for $1 \mathrm{~h}$. Upon cooling, $5 \mathrm{ml}$ of n-butanol:pyridine (15:1) was added. The mixture was vortexed for $1 \mathrm{~min}$ and centrifuged for $30 \mathrm{~min}$ at $1280 \mathrm{~g}$. The absorbance of the supernatant was measured at $532 \mathrm{~nm}$. A standard curve was generated using 1,1,3,3-tetramethoxypropane. The recovery was over $90 \%$. The results were expressed as nanomoles MDA per gram wet tissue (nmol/mg tissue).

\section{MPO activity}

MPO activity was measured according to the modified method of Bradley et $\mathrm{al}^{15}$. The homogenized samples were frozen and thawed three times, and centrifuged at $1500 \mathrm{~g}$ for $10 \mathrm{~min}$ at $4{ }^{\circ} \mathrm{C}$. MPO activity in the supernatant was determined by adding $100 \mathrm{ml}$ of the supernatant to $1.9 \mathrm{ml}$ of $10 \mathrm{mmol} / \mathrm{l}$ phosphate buffer (pH 6.0) and $1 \mathrm{ml}$ of $1.5 \mathrm{mM}$ o-dianisidine hydrochloride containing $0.0005 \%$ (wt/vol) hydrogen peroxide. The changes in absorbance at $450 \mathrm{~nm}$ of each sample were recorded on a UV-vis spectrophotometer. MPO activity in renal tissues was expressed as millimoles per minute per milligram tissue $(\mathrm{mmol} / \mathrm{min} / \mathrm{mg}$ tissue).

\section{GSH determination}

The amount of GSH in the gastric mucosa was measured according to the method of Sedlak and Lindsay ${ }^{16}$. The mucosal surface of the stomach was collected by scraping, weighed, and then homogenized in $2 \mathrm{ml} 50 \mathrm{mM}$ Tris- $\mathrm{HCl}$ buffer containing $20 \mathrm{mM}$ EDTA and $0.2 \mathrm{mM}$ sucrose, $\mathrm{pH} 7.5$. The homogenate was immediately precipitated with $0.1 \mathrm{ml}$ of $25 \%$ trichloroacetic acid, and the precipitate was removed by centrifugation at $1380 \mathrm{~g}$ for $40 \mathrm{~min}$ at $4{ }^{\circ} \mathrm{C}$. The supernatant was used to determine GSH using 5,5'-dithiobis(2-nitrobenzoic acid). Absorbance was measured at $412 \mathrm{~nm}$ using a spectrophotometer. The results of the GSH level in the mucosa were expressed as nanomoles per milligram tissue ( $\mathrm{nmol} / \mathrm{mg}$ tissue).

\section{GST activity}

Total GST activity was determined as described by Habig and Jakoby ${ }^{17}$. Briefly, the enzyme activity was assayed spectrophotometrically at $340 \mathrm{~nm}$ in a $4 \mathrm{ml}$ cuvette containing 0.1 M PBS (pH 6.5), $30 \mathrm{mM}$ glutathione, $30 \mathrm{mM}$ 1-chloro-2,6-dinitrobenzene and tissue homogenate.

\section{Determination of NO}

Determination of nitric oxide (NO): $\mathrm{NO}$ is readily oxidized to $\mathrm{NO}_{2}^{-}$and $\mathrm{NO}_{3}^{-}$since it is an extremely short-lived radical. For this reason, $\mathrm{NO}$ measurement was done after reduction of $\mathrm{NO}_{3}^{-}$existing in the ambient to $\mathrm{NO}_{2}^{-18}$.

\section{Histopathological analysis}

The kidneys of rats were fixed using $10 \%$ formaldehyde solution. Paraffin sections in $5 \mu \mathrm{m}$ thickness were cut from paraffin blocks prepared after tissue processing procedure, and the slides were stained with haematoxylin-eosin. The frequency and severity of renal lesions were evaluated on at least two tissue sections using the light microscope (Olympus CX51). The renal cortex and medulla were examined to determine the severity of renal damage.

\section{Statistical analysis}

All data were subjected to one-way ANOVA using SPSS 18.0 software. Differences among groups were attained using the least significant difference option and significance was declared at $p<0.05$. Results are the means \pm standard error of the mean. 
Table 1 The effect of mirtazapine on oxidative stress parameters in MTX induced nephrotoxicity in MTX (methotrexate), Mrtz+MTX (methotrexate + mirtazapine), and intact groups. Results are the mean \pm standard error of the mean. $N=6$ (number of animals).

\begin{tabular}{lcccccc}
\hline Drugs & Dose $(\mathrm{mg} / \mathrm{kg})$ & MDA & MPO & GSH & GST & NO \\
\hline MTX & 5 & $42.3 \pm 2.4$ & $31.3 \pm 1.9$ & $6.5 \pm 1.0$ & $5.7 \pm 0.8$ & $14.7 \pm 1.2$ \\
$p$ & & - & - & - & - & - \\
Mrtz+MTX & $30+5$ & $24.2 \pm 1.9$ & $19.7 \pm 1.8$ & $11.5 \pm 1.3$ & $10.5 \pm 1.1$ & $25.2 \pm 2.7$ \\
$p$ & & 0.0001 & 0.0001 & 0.007 & 0.007 & 0.004 \\
Intact & - & $21.2 \pm 1.6$ & $17.2 \pm 1.6$ & $14.0 \pm 1.1$ & $16.8 \pm 1.3$ & $33.5 \pm 2.3$ \\
$p$ & & 0.0001 & 0.0001 & 0.0001 & 0.0001 & 0.0001 \\
\hline
\end{tabular}

\section{RESULTS AND DISCUSSION}

The histopathologic and biochemical results of our study confirmed that MTX causes renal injury. When mirtazapine was given together with MTX to ascertain the effect of mirtazapine preventing from MTXrelated nephrotoxicity, mirtazapine provided a protective effect on renal damage developed with MTX reversing biochemical parameters indicating renal damage to almost control levels. Moreover, histopathologic examinations also demonstrated that mirtazapine had a protective effect on renal injury developed with MTX in rats.

In our study, it was observed that the levels of MDA and MPO significantly increased in the kidney tissue of MTX group in comparison with the intact group, whilst GSH and GST levels declined (Table 1). In the group of rats that received mirtazapine plus MTX, the levels of MDA, MPO, and GSH were similar to that of the group of intact animals and the difference between the groups was statistically insignificant. An increased level of MDA, which is one of the end-products of lipid peroxidation, represents an increase in free-oxygen radicals in the tissues ${ }^{19}$. The free radicals generate harmful effects initiating lipid peroxidation in the cell. MDA causes further damage in the cells ${ }^{20}$. In some studies, it was demonstrated that MDA and MPO levels were high, but the amounts of GSH and GST were low in the damaged renal tissue. These data are consistent with our MDA, MPO, GSH, and GST results achieved from both healthy and damaged tissues.

MPO enzyme existing within phagocytic cells (PNL) catalyses the production of toxic hypochlorous acid ( $\mathrm{HOCl}$ ) from $\mathrm{H}_{2} \mathrm{O}_{2}$. Excessive production of MPO and other reactive radicals result in oxidative damage because of the production of abundant amounts of superoxide anion $\left(\mathrm{O}^{2-}\right)$ and hydroxyl radical $\left(\mathrm{OH}^{-}\right)$by PNL cells. However, in the tissues antioxidant defensive mechanisms evolve against these toxic oxygen radicals. When these anti-oxidant defence mechanisms fail, severe damage occurs in the tissues ${ }^{21}$. The amount of MPO was found to be high in the kidney tissue of the rats given MTX in comparison with the group of intact rats. However, mirtazapine blocked significantly the elevation of MPO in the rat kidney tissue in comparison with MTX group.

$\mathrm{GSH}$, an anti-oxidant, reacts with peroxides and free radicals and transforms them to non-toxic products. GSH keeps -SH groups of proteins in reduced forms hindering their oxidation. With this mechanism, GSH protects the cells against oxidative damage that can be caused by free radicals ${ }^{22}$. In the kidney tissue of the rats given MTX, GSH, and GST levels were found to be much lower in comparison with the group of intact rats. But, the declines of GSH and GST levels were significantly blocked in the kidney tissue of rats given mirtazapine in comparison with MTX group. NO, also known as endothelial-derived relaxing factor, is released into circulation during hypoxia, endotoxin, or cellular damage stress ${ }^{23}$. Over increase in the intracellular concentrations of NO, triggers toxic events result in cell death ${ }^{24}$. Occurrence of $\mathrm{O}_{2}^{+}$is parallel with $\mathrm{NO}$, as they affect each other and cause the formation of $\mathrm{OH}^{\circ}$ and $\mathrm{NO}_{2}$. During this reaction toxic intermediate products such as peroxynitrite $\left(\mathrm{ONOO}^{-}\right)$and peroxynitrous acid $(\mathrm{ONOOH})$ occur $^{25}$.

There are studies suggesting that increased production of NO plays a role in renal damage and support the claiming that $\mathrm{NO}$ improves the renal damage occurring in renal disorders. In our study, the amount of NO was found to be lower in rats given MTX in comparison with the control group. When mirtazapine was given together with MTX, the amount of NO increases. These results are supported by the studies claiming remedial effect of $\mathrm{NO}$ on renal damage.

Oxygen free radicals not only acts on lipids but also reacts with DNA generating the mutagenic 8-hydroxyguanine, which is considered as an indicator 
Table 2 The effect of mirtazapine on renal function tests in MTX induced nephrotoxicity in MTX (methotrexate), Mrtz+MTX (methotrexate + mirtazapine), and intact groups. Results are the means \pm standard error of the mean.

\begin{tabular}{lrccc}
\hline Drugs & \multicolumn{1}{c}{ BUN } & $p$ & Cre & $p$ \\
\hline MTX & $140.3 \pm 6.3$ & - & $2.2 \pm 0.1$ & - \\
Mrtz+MTX & $70.0 \pm 3.9$ & 0.0001 & $1.3 \pm 0.1$ & 0.0001 \\
Intact & $38.7 \pm 2.2$ & 0.0001 & $0.70 \pm 0.04$ & 0.0001 \\
\hline
\end{tabular}

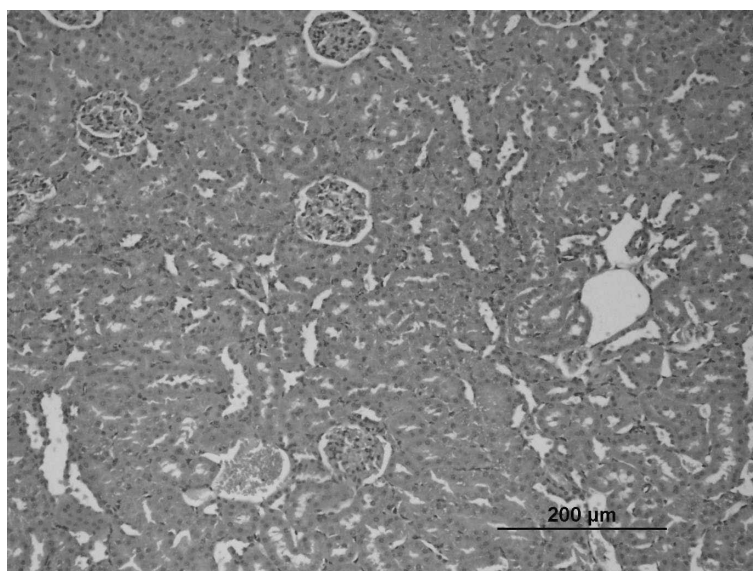

Fig. 1 Renal tissue (cortex) of intact group.

of DNA damage in tissue ${ }^{26}$. In recent studies it has been reported that 8-hydroxyguanine levels increase in tissues with reduced GSH and increased MDA levels ${ }^{27}$. GSH play roles in the prevention of potential damage of free radicals, inactivation of toxic substances, DNA synthesis, repair of damaged DNA fragments, and other metabolic functions ${ }^{28}$. Our results, together with the information obtained from literature, demonstrate that oxidants play an important role in DNA damage.

In our study, it was found that mirtazapine significantly decreased serum BUN and creatinine levels, which were increased due to methotrexate (Table 2). Serum BUN and creatinine are important biochemical parameters for measuring renal functions. Increases in serum BUN and creatinine concentrations are the indicators of severe kidney damage such as loss of functional nephrons. One evidence for the preventive effect of mirtazapine on nephrotoxicity is that mirtazapine blocked the increase in BUN and creatinine levels in blood samples of rats given methotrexate (Table 2).

\section{Histopathological analysis}

In the intact group, rats revealed normal renal morphology in both cortex and medulla (Fig. 1). Normal histomorphologic tissue is observed in cortex,

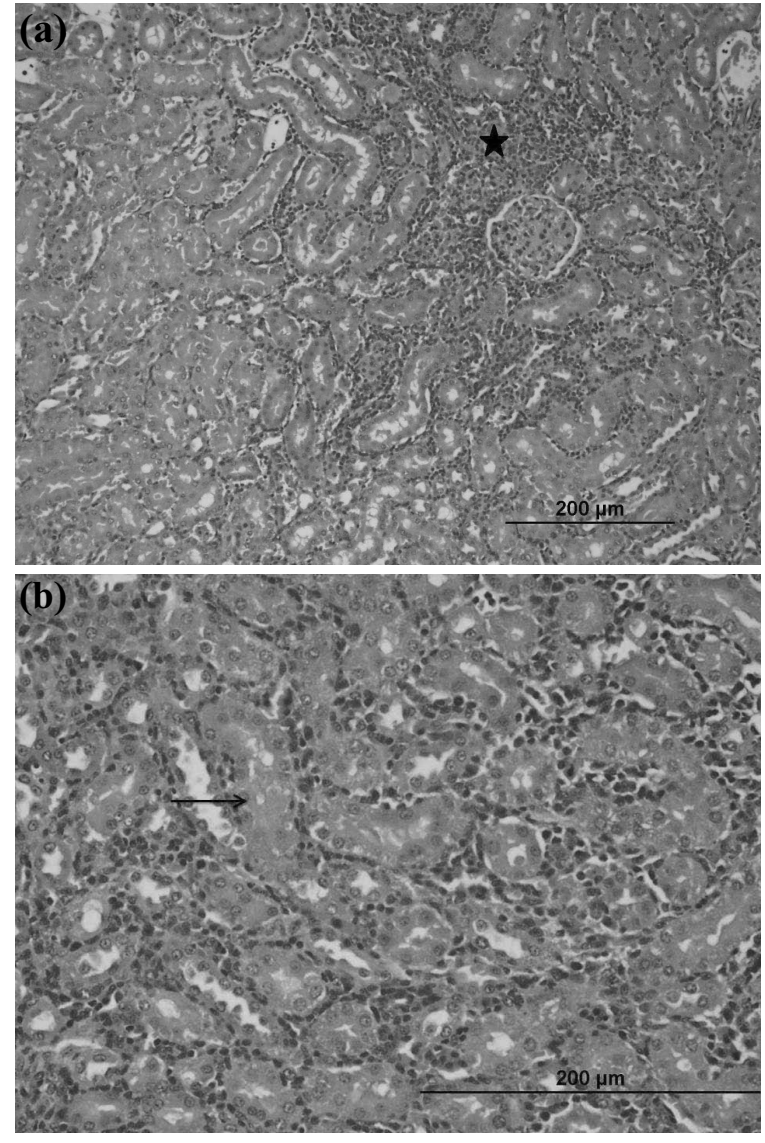

Fig. 2 Renal tissue (corticomedullary junction) of rats administered MTX.

glomeruli, proximal, and distal convoluted tubules. However, there were histopathologic signs such as interstitial inflammation, swelling, and desquamation in rats given MTX (Fig. 2). Fig. 2a shows dense mixed type tubulointerstitial inflammation $(\star)$ that is more prominent at the corticomedullary junction in the MTX-given group. There is remarkable swelling in the tubular epithelial cells and desquamated cells within the tubule lumen in the corticomedullary junction ( $\longrightarrow$ ) (Fig. 2b). No damage was observed in the glomeruli. Such pathological changes were absent in the kidney tissue of rats given mirtazapine (Fig. 3). Normal histomorphology was observed in the cortex (Fig. 3a) and medulla (Fig. 3b) in the group given mirtazapine + MTX. Tubulointerstitial inflammation and tubular damage was not observed in Fig. 3.

These results indicate that histopathological findings are consistent with the biochemical tests. Literature data and results from our study may suggest that the protective effect of mirtazapine on methotrexate nephrotoxicity results from its anti-oxidant activity. 

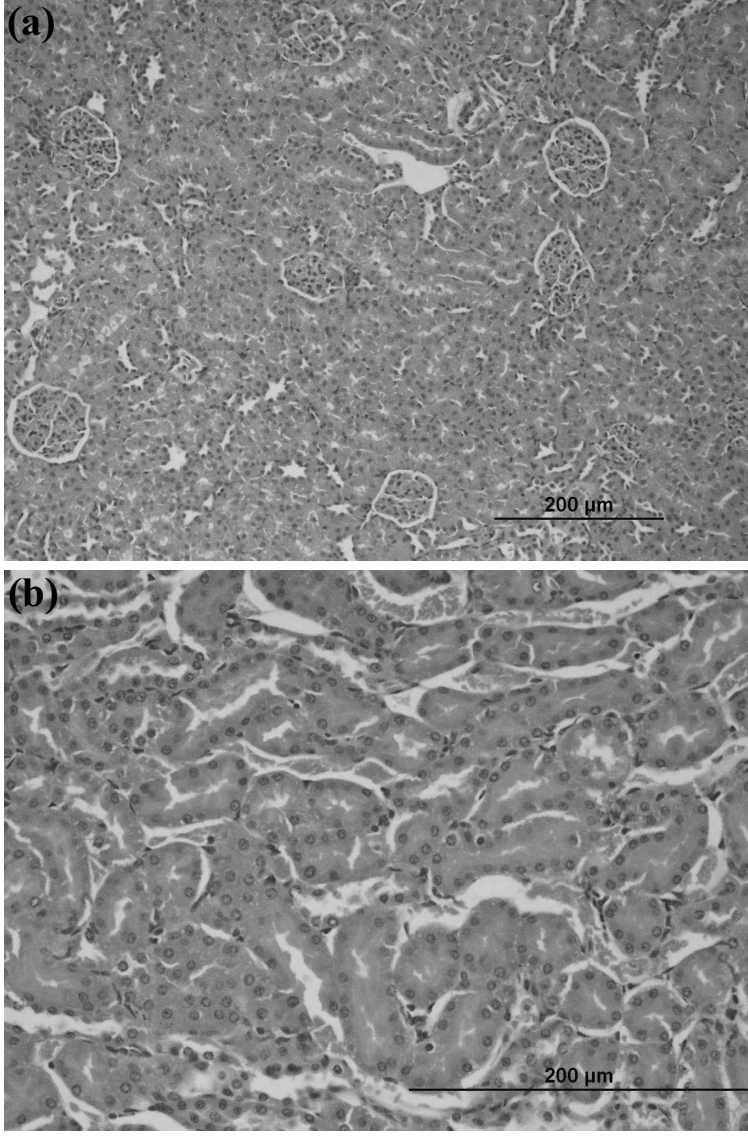

Fig. 3 Renal tissue (cortex and medulla) of rats given mirtazapine + methotrexate.

However, this does not mean that nephroprotective effect of mirtazapine is generated from its anti-oxidant property alone. Mirtazapine also blocks 5- $\mathrm{HT}_{2}$ and $5-\mathrm{HT}_{3}$ receptors ${ }^{29}$. It is known that stimulation of 5$\mathrm{HT}_{2}$ and $5-\mathrm{HT}_{3}$ receptors is associated with toxic side effects. For this reason, the role of these receptors can also be regarded in nephroprotective effect of mirtazapine. However, there is a need for further comprehensive studies to determine whether these receptors play a role in the mechanism of act of nephroprotective effect of mirtazapine. Maes and his colleagues proposed the role of oxidative mechanisms in the development of depression ${ }^{30}$. However, Bilici and his colleagues demonstrated the importance of the relationship between major depression and oxidant/antioxidant activities ${ }^{31}$. Studies on the pathogenesis of depression have shown that, inflammation occurs concomitantly with depression; inflammation is thought to be due to depression or it can lead to depression in process of time ${ }^{32}$. Müller and his colleagues reported that inflammation plays a role in

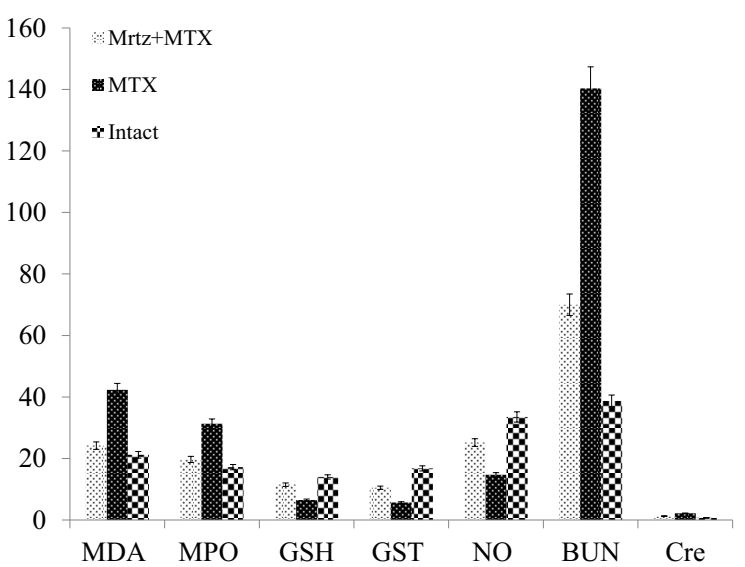

Fig. 4 The effect of mirtazapine on oxidative stress parameters in MTX induced nephrotoxicity in MTX (methotrexate), Mrtz+MTX (methotrexate + mirtazapine), and intact groups.

pathophysiology of depression and pro-inflammatory cytokines, and $\mathrm{PGE}_{2}$ increased in inflammation ${ }^{33}$. Information from the literature shows that, the antidepressant activity of mirtazapine may result from the antioxidant ability and the inhibition of PG and proinflammatory cytokines.

In conclusion, that mirtazapine was found to be efficacious to prevent nephrotoxicity due to MTX shows that MTX can be used safely in higher doses and for a longer course in combination with mirtazapine in cancer chemotherapy. To clarify this issue, more detailed studies must be done for DNA damage, such as protein nitration/nitrosylation measurements in the future.

\section{REFERENCES}

1. Albertioni F, Flato B, Seideman P, Beck O, Vinje O, Peterson C, Eksborg S (1995) Methotrexate in juvenile rheumatoid arthritis. Evidence of age dependent pharmacokinetics. Eur J Clin Pharmacol 47, 507-11.

2. Bright RD (1999) Methotrexate in the treatment of psoriasis. Cutis 64, 332-4.

3. Jolivet J, Cowan KH, Curt GA, Clendeninn NJ, Chabner BA (1983) The pharmacology and clinical use of methotrexate. New Engl J Med 309, 1094-104.

4. Te HS, Schiano TD, Kuan SF, Hanauer SB, Conjeevaram HS, Baker AL (2000) Hepatic effects of longterm methotrexate use in the treatment of inflammatory bowel disease. Am J Gastroenterol 95, 3150-6.

5. Izzedine H, Launay-Vacher V, Karie S, Caramella C, de Person F, Deray G (2005) Is low-dose methotrexate nephrotoxic? Case report and review of the literature. Clin Nephrol 64, 315-9.

6. Nyhlen A, Johnsson A, Hoglund P, Ljungberg B, 
Nilsson-Ehle I (1999) Gastrointestinal damage induced by cytostatic treatment does not affect the bioavailability of co-trimoxazole. Chemotherapy 45, 399-404.

7. Vezmar S, Becker A, Bode U, Jaehde U (2003) Biochemical and clinical aspects of methotrexate neurotoxicity. Chemotherapy 49, 92-104.

8. Kintzel PE (2001) Anticancer drug-induced kidney disorders: Incidence, prevention and management. Drug Saf 24, 19-38.

9. Jahovic N, Cevik H, Sehirli AO, Yegen BC, Sener G (2003) Melatonin prevents methotrexate-induced hepatorenal oxidative injury in rats. J Pineal Res 34, 282-7.

10. Uz E, Oktem F, Yilmaz HR, Uzar E, Ozguner F (2005) The activities of purine-catabolizing enzymes and the level of nitric oxide in rat kidneys subjected to methotrexate, protective effect of caffeic acid phenethyl ester. Mol Cell Biochem 277, 165-70.

11. Maes M, Galecki P, Chang YS, Berk M (2011) A review on the oxidative and nitrosative stress (O\&NS) pathways in major depression and their possible contribution to the (neuro)degenerative processes in that illness. Progr Neuro Psychopharmacol Biol Psychiatr 35, 676-92.

12. Tok A, Sener E, Albayrak A, Cetin N, Polat B, Suleyman B, Akcay F, Suleyman H (2012) Effect of mirtazapine on oxidative stress created in rat kidneys by ischemia-reperfusion. Ren Fail 34, 103-10.

13. Bilici M, Ozturk C, Dursun H, Albayrak F, Saglam MB, Uyanik A, Gulaboglu M, Tekin SB (2009) Protective effect of mirtazapine on indomethacin-induced ulcer in rats and its relationship with oxidant and antioxidant parameters. Dig Dis Sci 54, 1868-75.

14. Ohkawa H, Ohishi N, Yagi K (1979) Assay for lipid peroxides in animal tissues by thiobarbituric acid reaction. Anal Biochem 95, 351-8.

15. Bradley PP, Priebat DA, Christensen RD, Rothstein G (1982) Measurement of cutaneous inflammation, estimation of neutrophil content with an enzyme marker. J Investig Dermatol 78, 206-9.

16. Sedlak J, Lindsay RH (1968) Estimation of total, protein-bound, and nonprotein sulfhydryl groups in tissue with Ellman's reagent. Anal Biochem 25, 192-205.

17. Habig WH, Jakoby WB (1981) Assays for differentiation of glutathione S-transferases. Meth Enzymol 77, 398-405.

18. Moshage H, Kok B, Huizenga JR, Jansen PL (1995) Nitrite and nitrate determinations in plasma, a critical evaluation. Clin Chem 41, 892-6.

19. Girotti AW (1998) Lipid hydroperoxide generation, turnover, and effector action in biological systems. J Lipid Res 39, 1529-42.

20. Slater TF (1984) Free-radical mechanisms in tissue injury. Biochem J 222, 1-15.

21. Bast A, Haenen GR, Doelman CJ (1991) Oxidants and antioxidants, state of the art. Am J Med 91, 2-13.

22. Urso ML, Clarkson PM (2003) Oxidative stress, exercise, and antioxidant supplementation. Toxicology $\mathbf{1 8 9}$,
$41-54$.

23. Lin E, Lowry SF, Calvano SE (1999) The systemic response to injury. In: Schwartz SI (ed) Principles of Surgery, 7th edn, McGraw-Hill, pp 13-32.

24. Reiter RJ (1998) Oxidative damage in the central nervous system: protection by melatonin. Progr Neurobiol 56, 359-84.

25. Nordberg J, Arner ESJ (2001) Reactive oxygen species, antioxidants, and the mammalian thioredoxin system. Free Radic Biol Med 31, 1287-312.

26. Marnett LJ (2000) Oxyradicals and DNA damage. Carcinogenesis 21, 361-70.

27. Isaoglu U, Yilmaz M, Calik M, Polat B, Bakan E, Kurt A, Albayrak Y, Suleyman H (2012) Biochemical and histopathological investigation of the protective effect of disulfiram in ischemia-induced ovary damage. Gynecol Endocrinol 28, 143-7.

28. Chavan S, Sava L, Saxena V, Pillai S, Sontakke A, Ingole D (2005) Reduced Glutathione: Importance of Specimen Collection. Indian J Clin Biochem 20, 150-2.

29. Bruntoni LL (2010) Goodman and Gilman's The Pharmacological Basis of Therapeutics, 12th edn, The McGraw-Hill Companies.

30. Maes M, De Vos N, Pioli R, Demedts P, Wauters A, Neels H, Christophe A (2000) Lower serum vitamin E concentrations in major depression-Another marker of lowered antioxidant defenses in that illness. $J$ Affect Disord 58, 241-6.

31. Bilici M, Efe H, Koroglu MA, Uydu HA, Bekaroglu M, Deger O (2001) Antioxidative enzyme activities and lipid peroxidation in major depression: alterations by antidepressant treatments. J Affect Disord 64, 43-51.

32. Penninx BWJH, Kritchevsky SB, Yaffe K, Newman AB, Simonsick EM, Rubin S, Ferrucci L, Harris T, Pahor M (2003) Inflammatory markers and depressed mood in older persons: Results from the Health, Aging and Body Composition study. Biol Psychiatr 54, 566-72.

33. Müller N, Schwarz MJ, Dehning S, Douhe A, Cerovecki A, Goldstein-Müller B, Spellmann I, Hetzel G, et al (2006) The cyclooxygenase-2 inhibitor celecoxib has therapeutic effects in major depression: results of a double-blind, randomized, placebo controlled, add-on pilot study to reboxetine. Mol Psychiatr 11, 680-4. 